\title{
Production of Caffeine Alkaloid by Claviceps sorghi
}

\author{
Amauri Bogo ${ }^{1}$, Peter Gregory Mantle ${ }^{2}$, Mari Inês C. Boff ${ }^{1}$ \& Cassandro V. T. do Amarante ${ }^{1}$ \\ ${ }^{1}$ Centro de Ciências Agroveterinárias/CAV, Universidade do Estado de Santa Catarina/UDESC. Cx. Postal 281, \\ CEP 88520-000, Lages, SC, e-mail: a2ab@ cav.udesc.br; ${ }^{2}$ Biochemistry Department, Imperial College of Science, Technology and \\ Medicine, London, SW7-2AY, UK
}

(Accepted to publication on 27/03/2003)

Corresponding author: Amauri Bogo

BOGO, A., MANTLE, P.G. BOFF, M.I.C. \& DO AMARANTE, C.V. Production of caffeine alkaloid by Claviceps sorghi. Fitopatologia Brasileira 28:446-448. 2003.

\begin{abstract}
The ergot disease of sorghum (Sorghum bicolor), caused by the fungus Claviceps sorghi, restricted to the Indian subcontinent, is a disease in which the pathogen infects the florets, colonizing the unfertilized ovaries. Losses are higher in hybrid seed production fields due to a higher susceptibility of male sterile lines. The sclerotia of $C$. sorghi have never been found to contain

alkaloids with a tetracyclic ergoline ring system, which is normal in most ergot pathogens. In this work, we show that sclerotia of C. sorghi contain caffeine alkaloid and the ability to produce it in vitro.

Additional keywords: in vitro growth, sclerotia, alkaloid, Sorghum bicolor.

\section{RESUMO}

\section{Produção do alcalóide cafeína por Claviceps sorghi}

A doença ergot do sorgo (Sorghum bicolor), causada pelo fungo Claviceps sorghi, restrito ao Sub-continente Indiano, é uma doença na qual o patógeno infeta a flor, colonizando o ovário não fecundado. Os prejuízos são maiores em lavouras produtoras de sementes de híbridos, em razão do uso de linhas macho-estéreis,

que são mais suscetíveis à doença. Em esclerócios de C. sorghi, nunca foi encontrado nenhum tipo de alcalóide com sistema de anéis de ergolina tetracíclico, os quais são muito comuns nos patógenos das doenças ergot. Neste trabalho, é relatado que esclerócios de $C$. sorghi contêm o alcalóide cafeína e apresentam a capacidade de produzi-lo in vitro.
\end{abstract}

Sorghum [Sorghum bicolor (L.) Moench], is one of the most important cereal crops in the world, cultivated for food, feed, beverage, and fodder. The most significant technological change in the crop since the 1960s has been the development and use of $F_{1}$ hybrid seeds, susceptible to the ergot disease caused by Claviceps sorghi McRae (Bandyopadhyay et al., 1998).

Ergot is particularly severe in male-sterile lines when the fungus infects the ovaries. Instead of normal pollination, fertilization, and production of seed, ovaries are colonized by fungal hyphae that develop into spore-bearing fungal masses (Sphacelia), which exudes sweet, stick honeydew droplets as signs of the disease in the field (Bogo, 2001).

The three species of sorghum infecting Claviceps spp. pathogens are distinguished mainly by differences in morphology of ascostroma and sclerotia, and by alkaloid production. C. sorghi, restricted to the Indian Sub-continent, has never been found to contain alkaloids with tetracyclic ergoline ring system, which is normal in most sorghum ergot pathogens.

Caffeine, a notable alkaloid in tea (Camellia sinensis L.) (Theaceae) and coffee (Coffea arabica L.) (Rubiaceae) with important physiological, sociological and commercial implications, is also produced by plants such as "mate" (Ilex paraguariensis St. H.) (Aquifoliaceae), "guaraná" (Paullinia cupana Mart.) (Sapindaceae) and "cola" (Cola acuminata Schott \& Endl.) (Sterculiaceae) (Harborne et al., 1999). Recently, caffeine has even been found in anthers of Citrus spp. (Kretschmar \& Baumann, 1999). Caffeine is biosynthesised from adenine and methionine in tea (Suzuki \& Takahashi, 1976). Fungi have not previously been recognized as having the genome for such types of alkaloidal secondary metabolites, which are unique purine derivatives without a pentose, although Turner (1971) mentions a small group of adenosine derivatives containing a pentose, notably including cordycepin from Cordyceps militaris (Fr.) Link and Aspergillus nidulans Link. Ergot fungi (Claviceps sp.), taxonomically close to Cordyceps sp., usually produce classical ergot alkaloids based on the tetracyclic ergoline ring system. However, analysis of C. sorghi sclerotia and submerged culture identified a polar component as the alkaloid caffeine, which was identified by its characteristic electron impact mass spectrum (GC-MS).

\section{Ergot parasitism}

Male-sterile sorghum (IS 2219A) was grown in a horticultural tunnel at the Chelsea Physic Garden, London and flowered in August and September. Inflorescences were inoculated with C. sorghi at floret gaping by spraying diluted natural honeydew. New parasitic sphacelial tissues exuded honeydew one-two weeks after inoculation. Thereafter, they 
developed the characteristic spur-shaped, grey coloured sclerotia that were collected as host plants entered in senescence.

\section{Media and culture conditions}

Cultures of $C$. sorghi were maintained by subculturing every three weeks to slopes of sucrose/asparagine agar (Castagnoli \& Mantle, 1966). Modification of the medium for optimum alkaloid yield in liquid culture resulted in the following defined composition: sucrose, $150 \mathrm{~g}$; L-asparagine, $15 \mathrm{~g}$; $\mathrm{KH}_{2} \mathrm{PO}_{4}, 0.25 \mathrm{~g}: \mathrm{MgSO}_{4} \cdot 7 \mathrm{H}_{2} \mathrm{O}, 0.25 \mathrm{~g} ; \mathrm{FeSO}_{4} .7 \mathrm{H}_{2} \mathrm{O}, 0.033 \mathrm{~g}$; $\mathrm{ZnSO}_{4} .7 \mathrm{H}_{2} \mathrm{O}, 0.027 \mathrm{~g}$; distilled water, $1 \mathrm{l:} \mathrm{pH} 5.5$, adjusted with $\mathrm{NaOH}$. Erlenmeyer flasks $(500 \mathrm{ml})$, containing $100 \mathrm{ml}$ medium sterilized at $106^{\circ} \mathrm{C}$ for $20 \mathrm{~min}$, were inoculated with 1 to $2 \mathrm{ml}$ of a concentrated suspension of hyphal fragments and conidia obtained by homogenizing mycelium from agar cultures. Only a small proportion of the inoculum floated to the surface thus initiating surface growth, but it was found that the amount of 20-week-old mycelium that could conveniently be removed from a test-tube culture was sufficient when homogenized to inoculate two flasks. Flask cultures were incubated stationarily at $27^{\circ} \mathrm{C}$ in the dark. A course of fermentation was followed for 26 days by removing triplicate flasks at intervals, separating the surface mycelium from the culture filtrate and measuring the alkaloid in culture filtrate by the following analytical technique.

\section{Alkaloid extraction}

Finely powdered sclerotia and filtrate culture were submitted to a standard ergoline alkaloid extraction procedure and analysis (Mantle \& Waight, 1968). Extract was also chromatographed according to Ohmomo (1990). In the specific procedure for caffeine, powdered sclerotia and filtrate culture were extracted exhaustively in $\mathrm{CHCl}_{3}: \mathrm{MeOH}(2: 1)$. The solvents were then evaporated and the solutes treated with petroleum ether $\left(\mathrm{BP} 40-60^{\circ} \mathrm{C}\right)$ to dissolve triglyceride oils and ergosterol, and, finally, with a small volume of diethyl ether. Caffeine is only slightly soluble in these solvents. The residue, taken up in $\mathrm{CHCl}_{3}$, was chromatographed preparatively over silica gel $\left(\mathrm{Sil} \mathrm{G}_{254}, 1 \mathrm{~mm}\right.$ layer: Camlab) in toluene:EtOAc:HCOOH (15:4:1). The band corresponding to a caffeine standard was eluted with $\mathrm{MeOH}$ and evaporated to dryness. The remaining sclerotial powder was treated twice with boiling water to extract further caffeine. Extract was reduced to a small volume and extracted exhaustively with $\mathrm{CHCl}_{3}$, The extract was evaporated to dryness, and resolved chromatographically as above to isolate the caffeine.

Chromatograms of $50 \mathrm{~g}$ of powdered sclerotia and $3.5 \mathrm{~g}$ (from $100 \mathrm{ml}$ medium) of dry weight mycelium extract at the final stage of the standard extraction process for ergoline alkaloids of sclerotia and culture filtrate of $C$. sorghi failed to reveal typical Ehrlich-positive ergoline alkaloids. However, the polar component of a $\mathrm{UV}_{254}$-absorbing band near the origin of the chromatogram gave an electron impact mass spectrum (Figure 1A) which was identical to that of a reference sample of caffeine (Figure 1B). The accurate mass of the molecular ion $\left(\mathrm{m} / 2\right.$ 194.0820) corresponded to $\mathrm{C}_{8} \mathrm{H}_{10} \mathrm{~N}_{4} \mathrm{O}_{2}$ (calculated mass 194.0804) and the compound co-chromatographed with caffeine in TLC. The next most important fragment ion $(\mathrm{m} / \mathrm{z}$ 109.0656) corresponded to $\mathrm{C}_{5} \mathrm{H}_{7} \mathrm{~N}_{3}$ (calculated mass 109.0613), involving a loss of $\mathrm{C}_{3} \mathrm{H}_{3} \mathrm{NO}_{2}$ from the molecular ion.

Caffeine was also recognized by GC-MS (Fisons MD 800 ) as corresponding to the authentic compound, using a small amount of initial extract from the chromatogram band, the process followed the steps of sclerotial and culture filtrate extraction for ergot alkaloid involving diethyl ether; partition into dilute tartaric acid and, after adjusting to alkaline $\mathrm{pH}$, partition into $\mathrm{CHCl}_{3}$; and, finally, evaporation to dryness and dissolution in hexane $(100 \mu \mathrm{l})$. The total amount of caffeine was estimated from a closely matched GC-MS total ion current yield from $1 \mu \mathrm{g}$ of caffeine injected also in $1 \mu \mathrm{l}$ of hexane.

The band corresponding to caffeine, eluted with $\mathrm{MeOH}$, gave $200 \mu \mathrm{g}$ of white crystalline product per $3.5 \mathrm{~g}$ of dry weight mycelium extract and $4.2 \mathrm{mg}$ per $50 \mathrm{~g}$ of powdered sclerotia. GC-MS (Micromass Autospek Q) analysis proved purity and confirmed mass spectral data for caffeine (Figure1B).

To insure that all caffeine was extracted, the remained sclerotial powdered material and dry mycelium were re-extracted twice with boiling water, evaporated to a small volume and extracted exhaustively with $\mathrm{CHCl}_{3}$. Extracted solutes were chromatographed preparatively over silica gel to afford more caffeine, giving a total yield of $16.6 \mathrm{mg}(4.2+12.4 \mathrm{mg})$ caffeine from $50 \mathrm{~g}$ sclerotia $(0.03 \% \mathrm{w} / \mathrm{w}$; cf. typical ergoline alkaloid content of $C$. purpurea (Fr.) Tul. sclerotia $0.2-0.5 \%$ ). and any trace of caffeine from $3.5 \mathrm{~g}$ of dry mycelium.

The finding of caffeine, not only as a fungal metabolite but also as a significant natural product of an ergot fungus, adds to the range of alkaloidal biosynthesis within the Clavicipitaceae, but it is not yet known whether the pathway is the same as in plants. Our additional finding of caffeine production in submerged fermentation of this fungus may facilitate such study. It also confirms that a host plant is not the source of sclerotial caffeine. Within the current natural ergot pathogens of sorghum, caffeine is therefore a valuable diagnostic feature for parasitic C. sorghi sclerotial tissue, as dihydroergosine is for C. africana Frederickson, Mantle, and de Milliano and paliclavine is for C. sorghicola Tsukiboshi, Shimanuki, and Uematasu.

The anamorph of the three Claviceps species cited above is Sphacelia sorghi McRae that is morphologically indistinguishable between them, and it is important not to be confused by literature in which $C$. africana seems to have been misnamed as C. sorghi (Bandyopadhyay et al., 1990; Ferreira \& Casela, 1995). The three species are distinguished by their teleomorph morphology and also by molecular characters, as recently demonstrated by Pazoutova \& Bogo (2001). There is a need to re-examine the taxonomy and variation of the Claviceps species based on alkaloid production and using a large number of isolates from different geographic areas in order to determine the genetic relationships among them. Whereas $C$. sorghi is highly infective of a male-sterile form as shown in the present study, agronomic loss in seed 

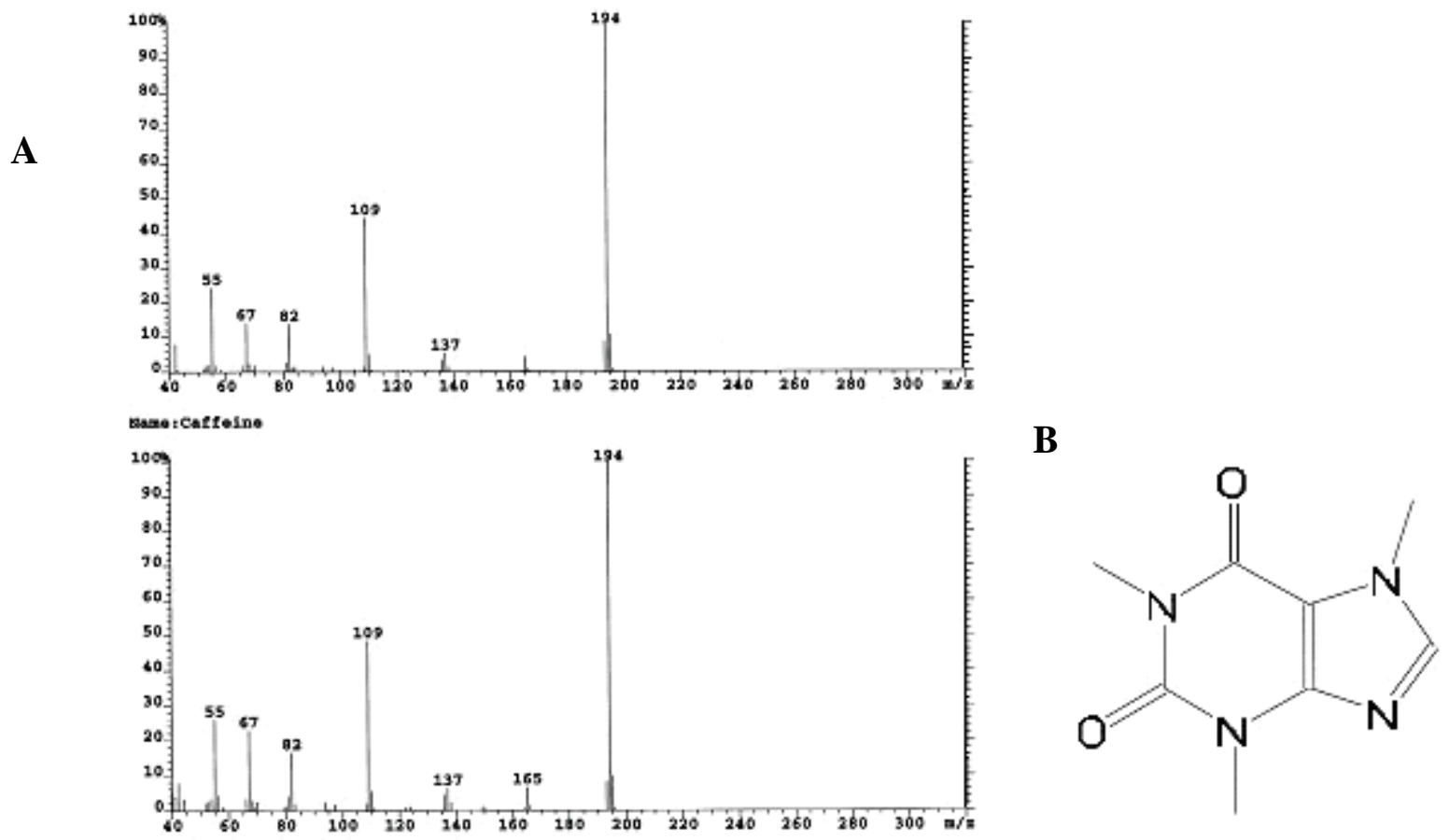

FIG. 1 - (A) Electron impact mass spectrum of caffeine from Claviceps sorghi (B) Data from U.S. National Institutes of Science and Technology (NIST) Database and (C) Molecular structure of caffeine.

yield does not seem to be due to toxigenicity of any sclerotial contaminant.

\section{LITERATURE CITED}

CASTAGNOLI, N. \& MANTLE, P.G. Occurrence of D-lysergic acid and 6-methyl-ergot-8-ene-8-carboxylic acid in culture of Claviceps purpurea. Nature 211:859-860. 1966.

BANDYOPADHYAY, R., FREDERICKSON, D., McLAREN, N., ODVODY, G.N. \& RYLEY, M.J. Ergot: a new disease threat to sorghum in the Americas and Australia. Plant Disease 82:356-367. 1998.

BANDYOPADHYAY, R., MUGHOGHO, L.K., MANOHAR, S.K. \& SATYANARAYANA, M.V. Stroma development, honeydew formation and conidial production in Claviceps sorghi. Phytopathology 80:812-819. 1990.

BOGO, A. Biochemical physiopathology of some ergot fungi and other honeydew-producing plant parasites. (Ph.D. Thesis), London. University of London. 2001.

FERREIRA, A.S. \& CASELA, C.R. Ocorrência da Claviceps sorghi, agente causal da doença ergot no Brasil. Fitopatologia Brasileira 20:302. 1995. (Resumo)

FREDERICKSON, D.E., MANTLE, P.G. \& DE MILLIANO, W.A.J. Claviceps africana sp. nov.: the distinctive ergot pathogen of sorghum in Africa. Mycological Research 95:1101-1107. 1991.
HARBORNE, J.B., BAXTER, H. \& MOSS, G.P. Phytochemical Dictionary: A Handbook of bioactive compounds from plants. 2ed. London. Taylor \& Francis. 1999.

KULKARNI, B.G.P., SESHARDI, V.S. \& HEGDE, R.K. The perfect stage of Sphacelia sorghi McRae. Mysore Journal of Agricultural Science 10:286-289. 1976.

KRETSCHMAR, J.A. \& BAUMANN, T.W. Caffeine in Citrus flowers. Phytochemistry 52:19-23. 1999.

MANTLE, P.G. \& WAIGHT, E.S. Dihydroergosine: a new naturally occurring alkaloid from the sclerotia of Sphacelia sorghi McRae. Nature 218:581-582. 1968.

OHMOMO, S. Some aspects of alkaloids detected in sorghum ergot sclerotia in Japan. Current Topics of Pasture Research in Japan 5:4950. 1990.

PAZOUTOVA, S. \& BOGO, A. Rediscovery of Claviceps sorghi (Ascomycotina: Clavicipitaceae) in India. Mycopathologia 153:99101. 2001.

SUZUKI, T. \& TAKAHASHI, I. Caffeine biosynthesis in Camellia sinensis. Phytochemistry 15:1235-1239. 1976.

TSUKIBOSHI, T., SHIMANUKI, T. \& UEMATSU, T. Claviceps sorghicola sp. nov., a destructive ergot pathogen of sorghum in Japan. Mycological Research 103:1403- 1408. 1999.

TURNER, W.B. Fungal Metabolites. 3nd. ed. London. Academic Press. 1971. 